\title{
Faunistic analysis of Carabidae and Staphylinidae (Coleoptera) in five agroecosystems in northeastern São Paulo state, Brazil
}

\author{
Francisco Jorge Cividanes ${ }^{(1)}$, José Carlos Barbosa ${ }^{(2)}$, Sérgio Ide ${ }^{(3)}$, Nelson Wanderlei Perioto ${ }^{(4)}$ \\ and Rogéria Inês Rosa Lara(4)
}

\begin{abstract}
(1)Universidade Estadual Paulista (Unesp), Faculdade de Ciências Agrárias e Veterinárias (FCAV), Departamento de Fitossanidade, Via de Acesso Prof. Paulo Donato Castellane, s/no, CEP 14884-900 Jaboticabal, SP, Brazil. E-mail: fjcivida@fcav.unesp.br (2)Unesp, FCAV, Departamento de Ciências Exatas. E-mail: jcbarbosa@fcav.unesp.br ${ }^{(3)}$ Agência Paulista de Tecnologia dos Agronegócios (APTA), Avenida Conselheiro Rodrigues Alves, № 1.252, CEP 04014-900 São Paulo, SP, Brazil. E-mail: ide@biologico.sp.gov.br ${ }^{\left({ }^{(4)} A P T A, ~ A v e n i d a ~\right.}$ Bandeirantes, no 2.419, CEP 14030-670 Ribeirão Preto, SP, Brazil. E-mail: nperioto@apta.sp.gov.br, rirlara@yahoo.com.br
\end{abstract}

\begin{abstract}
The objective of this study was to determined species composition and community structure of Carabidae and Staphylinidae in five areas of forest fragment and soybean/corn crops or orange orchard, from December 2004 to May 2007. Beetles were captured in pitfall traps distributed along two parallel transects of $200 \mathrm{~m}$ in length, placed across crop land/forest boundary fragment, with $100 \mathrm{~m}$ each. The Shannon-Wiener diversity and evenness indexes and Morisita similarity index were calculated. The carabids Abaris basistriatus Chaudoir, Calosoma granulatum Perty, Megacephala brasiliensis Kirby, Odontochila nodicornis (Dejean) and Selenophorus seriatoporus Putzeys. are dominant and are widely distributed in northeastern São Paulo state, Brazil. Point-scale species diversity was greatest at the transition between forest fragment and cultivated area. The carabid and staphylinid communities of the forest fragment were more similar to the community of orange orchard than that of soybean/corn crops.
\end{abstract}

Index terms: Citrus sinensis, Glycine max, Zea mays, diversity, no-tillage, similarity.

\section{Análise faunística de Carabidae e Staphylinidae (Coleoptera) em cinco agroecossistemas da Região Nordeste do Estado de São Paulo}

\begin{abstract}
Resumo - O objetivo deste estudo foi determinar a composição de espécies e a estrutura das comunidades de Carabidae e Staphylinidae, em cinco áreas de fragmento florestal e cultura soja/milho ou pomar laranja, de dezembro de 2004 a maio de 2007. Os besouros foram capturados com armadilhas de solo, distribuídas em dois transectos paralelos de $200 \mathrm{~m}$ de comprimento, com $100 \mathrm{~m}$ no interior da área cultivada e $100 \mathrm{~m}$ no interior do fragmento florestal. A fauna foi caracterizada pelos índices de diversidade e equitabilidade de Shannon-Wiener e pelo de similaridade de Morisita. Os carabídeos Abaris basistriatus Chaudoir, Calosoma granulatum Perty, Megacephala brasiliensis Kirby, Odontochila nodicornis (Dejean) e Selenophorus seriatoporus Putzeys. são as espécies dominantes com maior distribuição geográfica na região nordeste do Estado de São Paulo. A maior diversidade de espécies de carabídeos e estafilinídeos ocorreu na transição entre fragmento florestal e área cultivada. As comunidades de carabídeos e estafilinídeos de fragmento florestal tiveram maior similaridade com a comunidade do pomar de laranja do que com a de cultura soja/milho.
\end{abstract}

Termos para indexação: Citrus sinensis, Glycine max, Zea mays, diversidade, plantio direto, similaridade.

\section{Introduction}

Agricultural practices have led to landscape simplification and, in many cases, to a reduction in diversity and abundance of native fauna (Pfiffner \& Luka, 2000). The families of ground beetles (Carabidae) and rove beetles (Staphylinidae) include predator species and are potentially important natural pest-control agents, in agricultural soils (Kromp, 1999; Holland \& Luff, 2000; Suenaga \&
Hamamura, 2001). Natural habitats surrounding agricultural fields provide a source of biota to assist in pest control, but the boundaries are filters, which result in diverse communities within the agroecosystems (French et al., 2001). The diversity and abundance of ground and rove beetles in crops can be positively correlated with the presence of forest fragments and similar natural habitats, contributing to the sustainability of the agriculture (Kromp, 1999). However, individual species are 
not linked to specific crops, and differences between carabid assemblages generally reflect cultivation practices rather than the preference of individual beetle species for particular crops (Holland \& Luff, 2000). Changes in practices which favour beneficial arthropods in agroecosystems, for example, no-tillage systems (Andersen, 2003), would also be expected to affect predatory beetles.

Quantitative studies of arthropod predators have been recommended to test the hypothesis that diversity is positively correlated with stability, productivity and complexity in agroecosystems (Rieske \& Buss, 2001; Watt et al., 2002).

The objective of this study was to determine species composition and community structure of Carabidae and Staphylinidae in five areas of forest fragment and soybean/corn crops or orange orchards.

\section{Materials and Methods}

The study was carried out in five areas, in four municipalities of the northeast region of São Paulo state, Brazil, from December 2004 to May 2007. Area J (Jaboticabal county, no-tillage system) was located at the Campus of Universidade Estadual Paulista, in Jaboticabal county $\left(21^{\circ} 14 ' 52^{\prime \prime S}\right.$, $\left.48^{\circ} 16^{\prime} 04^{\prime \prime} \mathrm{W}\right)$. The soil is classified as an Oxisol. The site comprised 40 ha cultivated with soybean [Glycine $\max$ (L.) Merrill] rotated with corn [Zea mays (L.)], in a no-tillage system, adjacent to 15 ha of semi-deciduous broadleaf tropical forest fragment. The areas with no-tillage system (Gd) and with conventional-tillage system $(\mathrm{Gc})$ were located in Guaíra county $\left(20^{\circ} 21^{\prime} 10^{\prime \prime} \mathrm{S}, 48^{\circ} 14^{\prime} 47^{\prime \prime} \mathrm{W}\right.$ and $20^{\circ} 19^{\prime} 29^{\prime \prime} \mathrm{S}$, $48^{\circ} 15^{\prime} 08^{\prime \prime} \mathrm{W}$, respectively), about $2 \mathrm{~km}$ from one another. The soil is also classified as an Oxisol. The area $\mathrm{Gd}$ comprised a 90 ha field cultivated with soybean rotated with corn, in a no-tillage system, adjacent to 48 ha of a semi-deciduous broadleaf tropical forest fragment. Both in Jaboticabal and Guaíra areas, the field edge was characterized by 3-m bare soil strip with few herbaceous plants, while in the other areas herbaceous plants were present right to the field boundary. The area Gc had 15 ha cultivated with soybean rotated with corn, in a conventional tillage system, and was adjacent to 6 ha of a semi-deciduous broadleaf tropical forest fragment. The area Gavião Peixoto-orange orchard (GP) was located in Gavião Peixoto county $\left(21^{\circ} 49^{\prime} 19^{\prime \prime} \mathrm{S}, 48^{\circ} 24^{\prime} 46^{\prime \prime} \mathrm{W}\right)$. The soil is classified as an Ultisol. The site comprised 10 ha of an orange orchard [Citrus sinensis (L.) Osbeck] adjacent to 19 ha of a semi-deciduous broadleaf tropical forest fragment. The area Descalvado-orange orchard (D) was located in Descalvado county $\left(21^{\circ} 54^{\prime} 09^{\prime \prime} \mathrm{S}\right.$, $\left.47^{\circ} 43^{\prime} 55^{\prime \prime} \mathrm{W}\right)$. The soil is classified as an Oxisol. The site comprised 800 ha of an orange orchard adjacent to 2,000 ha of a Brazilian savanna fragment.

The insects were sampled by pitfall traps, distributed in two parallel 200-m transects, $10-\mathrm{m}$ apart (Bedford \& Usher, 1994). Each transect spanned the habitat boundary, with $100 \mathrm{~m}$ in the crop field and $100 \mathrm{~m}$ in the forest fragment. Four traps were set close to each other $(1 \mathrm{~m})$ in the crop, at its boundary with the forest fragment, and from this point on additional traps were installed at $10-\mathrm{m}$ intervals. Sampling was biweekly during the crop seasons, and monthly otherwise. At each sampling date, traps were set and remained in the field for one week. Beetles were preserved for identification at the Insect Ecology Laboratory, at Unesp, Jaboticabal Campus. The carabids and staphylinids were identified to species level in the Agência Paulista de Tecnologia dos Agronegócios (APTA). Beetle communities were assessed by the Shannon-Wiener and Morisita indices (Brower et al., 1998). Species with the largest abundance, dominance, frequency and constancy faunistic indices (Moraes et al., 2003) were designated as dominant.

\section{Results and Discussion}

A total of 4,880 carabid and 1,043 staphylinid individuals were captured, representing 98 and 95 carabid and staphylinid morphospecies, respectively. Among the carabids classified as dominant species, Abaris basistriatus Chaudoir and Selenophorus seriatoporus Putzeys. prevailed in five and four experimental areas, respectively, while Megacephala brasiliensis Kirby, Odontochila nodicornis (Dejean) and Calosoma granulatum Perty dominated in three areas (Table 1). Few staphylinids were classified as dominant species. Xenopygus sp. 2 reached this status in both areas of 
orange orchard (Descalvado and Gavião Peixoto), and Eulissus chalybaeus Mannerheim, in the Gd area. According to Ellsbury et al. (1998), the identification of dominant species of arthropod predators is the first step in the development of biological control programs in agroecosystems.

The highest diversity and evenness coefficients for carabids and staphylinids species were observed in areas with forest fragment and soybean/corn crops under no-tillage system or orange orchard; the opposite was observed in soybean/corn crops cultivated by a conventional tillage system (Table 2). High diversity coefficients indicate well-structured insect communities (Brower et al., 1998). So, in the areas with crops whose soil was not disturbed by cultivation, the carabid and staphylinid communities contained few notably dominant species and had higher evenness compared with annual crops under conventional tillage.

The present results are in agreement with those of Magura (2002), who showed that species diversity was greater at the boundary between forest fragments and cultivated areas than in the centre of these habitats (Table 2). However, forest fragments in Gd (48 ha) and D (2,000 ha) that showed higher carabid and staphylinid diversity, compared with the

Table 1. Dominant Carabidae and Staphylinidae species, captured in forest fragments and soybean/corn crops or orange orchards, in five areas of the northeast region of São Paulo state, Brazil.

\begin{tabular}{|c|c|}
\hline Species & Area $^{(1)}$ \\
\hline \multicolumn{2}{|l|}{ Carabidae } \\
\hline Abaris basistriatus Chaudoir & $\mathrm{J}, \mathrm{Gd}, \mathrm{Gc}, \mathrm{GP}, \mathrm{D}$ \\
\hline Athrostictus sp.1 & GP \\
\hline Calosoma granulatum Perty & $\mathrm{J}, \mathrm{Gd}, \mathrm{Gc}$ \\
\hline Apenes aenea (Dejean) & Gc \\
\hline Megacephala brasiliensis Kirby & J, Gd, GP \\
\hline Odontochila cupricollis Kollar & $\mathrm{J}, \mathrm{Gd}$ \\
\hline Odontochila nodicornis (Dejean) & $\mathrm{Jb}, \mathrm{Gd}$ \\
\hline Pseudabarys sp.1 & GP \\
\hline Scarites sp. 2 & $\mathbf{J}$ \\
\hline Scarites sp.3 & $\mathrm{J}, \mathrm{Gd}$ \\
\hline Scarites sp.4 & $\mathrm{Gd}, \mathrm{Gc}$ \\
\hline Selenophorus alternans Dejean & J, D \\
\hline Selenophorus seriatoporus Putz. & $\mathrm{J}, \mathrm{Gd}, \mathrm{Gc}, \mathrm{GP}$ \\
\hline Selenophorus sp.4 & GP, D \\
\hline Tetragonoderus laevigatus Chaudoir & $\mathrm{D}$ \\
\hline \multicolumn{2}{|l|}{ Staphylinidae } \\
\hline Eulissus chalybaeus Mannerheim & Gd \\
\hline Xenopygus sp. 2 & GP, D \\
\hline
\end{tabular}

forest fragments of the areas J (15 ha), GP (19 ha) and Gc (6 ha). According to some authors (Davies \& Margules, 1998; Niemelä, 2001), the forest fragmentation affects beetle abundance more than diversity. Among the abundant species observed in the present study, A. basistriatus was designated dominant in all areas (Table 1). This carabid species is classified as a generalist in habitat preference, is less susceptible to forest fragmentation (Davies \& Margules, 1998) and, therefore, occurs both in soybean/corn crop fields and forest fragments (Cividanes \& Santos-Cividanes, 2008). Other dominating species, identified in the present study, were $S$. seriatoporus (captured in four areas), and C. granulatum, $M$. brasiliensis and $O$. nodicornis (captured in three areas). C. granulatum and $M$. brasiliensis were associated with soybean/ corn crops, and $O$. nodicornis with forest fragment (Cividanes \& Santos-Cividanes, 2008).

A high degree of similarity was observed between the communities of carabids and staphylinids from the forest fragments and orange orchards of Gavião Peixoto and Descalvado, while in the Jaboticabal and Guaíra areas, the similarity of the communities from forest and annual crops was low (Table 3). The results suggest that the orange orchards were more favorable to beetle species of forest fragment origin. This conclusion supports Thiele's (1977), who suggested that carabids in agricultural areas are remnants of the original forest fauna, but may also indicate a high probability of movement of individuals between the habitats (Kajak \& Lukasiewicz, 1994). Likewise, not only the high similarity coefficient for the forest fragment and

Table 2. Shannon-Wiener diversity $(\mathrm{H})$ and evenness (E) coefficients for Carabidae and Staphylinidae, in different habitats of the northeast region of São Paulo state, Brazil.

\begin{tabular}{|c|c|c|c|c|c|c|}
\hline \multirow[t]{2}{*}{ Area } & \multicolumn{2}{|c|}{$\begin{array}{c}\text { Forest } \\
\text { fragments }\end{array}$} & \multicolumn{2}{|c|}{ Crops } & \multicolumn{2}{|c|}{$\begin{array}{l}\text { Field } \\
\text { edge }\end{array}$} \\
\hline & $\mathrm{H}$ & $\mathrm{E}$ & $\mathrm{H}$ & $\mathrm{E}$ & $\mathrm{H}$ & $\mathrm{E}$ \\
\hline $\begin{array}{l}\text { Jaboticabal } \\
\text { (no-tillage) }\end{array}$ & 2.23 & 0.61 & 2.84 & 0.72 & 3.06 & 0.78 \\
\hline $\begin{array}{l}\text { Guaíra } \\
\text { (no-tillage) }\end{array}$ & 2.81 & 0.76 & 2.37 & 0.66 & 2.65 & 0.72 \\
\hline $\begin{array}{l}\text { Guaíra } \\
\text { (conventional tillage) }\end{array}$ & 1.85 & 0.54 & 1.41 & 0.43 & 2.34 & 0.66 \\
\hline $\begin{array}{l}\text { Gavião Peixoto } \\
\text { (orange orchard) }\end{array}$ & 2.25 & 0.62 & 2.64 & 0.66 & 3.03 & 0.80 \\
\hline $\begin{array}{l}\text { Descalvado } \\
\text { (orange orchard) }\end{array}$ & 2.79 & 0.73 & 2.52 & 0.59 & 2.95 & 0.76 \\
\hline
\end{tabular}


Table 3. Morisita similarity coefficients, for Carabidae and Staphylinidae, in different habitats of the northeast region of São Paulo state, Brazil.

\begin{tabular}{lccc}
\hline Area & $\begin{array}{c}\text { Forest fragment } \\
\text { x crop }\end{array}$ & $\begin{array}{c}\text { Forest fragment } \\
\text { x field edge }\end{array}$ & $\begin{array}{c}\text { Crop x field } \\
\text { edge }\end{array}$ \\
\hline $\begin{array}{l}\text { Jaboticabal } \\
\text { (no-tillage) }\end{array}$ & 0.250 & 0.506 & 0.787 \\
$\begin{array}{l}\text { Guaíra } \\
\text { (no-tillage) }\end{array}$ & 0.203 & 0.305 & 0.379 \\
$\begin{array}{l}\text { Guaíra } \\
\text { (conventional tillage) }\end{array}$ & 0.070 & 0.934 & 0.159 \\
$\begin{array}{l}\text { Gavião Peixoto } \\
\text { (orange orchard) }\end{array}$ & 0.525 & 0.401 & 0.839 \\
$\begin{array}{l}\text { Descalvado } \\
\text { (orange orchard) }\end{array}$ & 0.730 & 0.546 & 0.547 \\
\hline
\end{tabular}

edge of the Gc area indicates assemblage similarity between these habitats, but also suggests migration between them (Table 3). Luff (2002) and Hofmann \& Mason (2006) took the view that soil and crop conditions were also important for carabid and staphylinids species in agricultural areas.

In Jaboticabal and Gavião Peixoto, the carabid and staphylinid communities of the edge strip and crop showed the highest similarity (Table 3 ). As carabids usually disperse by walking (French et al., 2001), but are inhibited by fences, tracks and roads (Thomas et al., 2002), it may be more difficult for beetle migration to take place between forest and crop field.

\section{Conclusions}

1. Abaris basistriatus, Calosoma granulatum, Megacephala brasiliensis, Odontochila nodicornis and Selenophorus seriatoporus are dominant species and have a wide geographical distribution in northeastern São Paulo state.

2. The highest carabid and staphylinid species diversity occurs at the field edge between forest fragments and cultivated areas.

3. The carabid and staphylinid communities of orange orchards are more similar to the ones of adjacent forest fragments than to those of soybean/corn crops.

\section{Acknowledgements}

To Fundação de Amparo à Pesquisa do Estado de São Paulo (Fapesp), for financial support; to Conselho Nacional de Desenvolvimento Científico e Tecnológico (CNPq), for financial support and for providing a scholarship.

\section{References}

ANDERSEN, A. Long-term experiments with reduced tillage in spring cereals. II. Effects on pests and beneficial insects. Crop Protection, v.22, p.147-152, 2003.

BEDFORD, S.E.; USHER, M.B. Distribution of arthropod species across the margins of farm woodlands. Agriculture, Ecosystems \& Environment, v.48, p.295-305, 1994.

BROWER, J.E.; ZAR, J.H.; ENDE, C.N. von. Field and laboratory methods for general ecology. $4^{\text {th }}$ ed. Boston: McGraw-Hill, 1998. $273 p$.

CIVIDANES, F.J.; SANTOS-CIVIDANES, T.M. dos. Distribuição de Carabidae e Staphylinidae em agroecossistemas. Pesquisa Agropecuária Brasileira, v.43, p.157-162, 2008.

DAVIES, K.F.; MARGULES, C.R. Effects of habitat fragmentation on carabid beetles: experimental evidence. Journal of Animal Ecology, v.67, p.460-471, 1998.

ELLSBURY, M.M.; POWELL, J.E.; FORCELLA, F.; WOODSON, W.D.; CLAY, S.A.; RIEDELL, W.E. Diversity and dominant species of ground beetle assemblages (Coleoptera: Carabidae) in crop rotation and chemical input systems for the Northern Great Plains. Annals of the Entomological Society of America, v.91, p.619-625, 1998.

FRENCH, B.W.; ELLIOTT, N.C.; BERBERET, R.C.; BURD, J.D. Effects of riparian and grassland habitats on ground beetle (Coleoptera: Carabidae) assemblages in adjacent wheat fields. Environmental Entomology, v.30, p.225-234, 2001.

HOFMANN, T.A.; MASON, C. F. Importance of management on the distribution and abundance of Staphylinidae (Insecta: Coleoptera) on coastal grazing marshes. Agriculture, Ecosystems \& Environment, v.114, p.397-406, 2006.

HOLLAND, J.M.; LUFF, M.L. The effects of agricultural practices on Carabidae in temperate agroecosystems. Integrated Pest Management Reviews, v.5, p.109-129, 2000.

KAJAK, A.; LUKASIEWICZ, J. Do semi-natural patches enrich crop fields with predatory epigean arthropods? Agriculture, Ecosystems \& Environment, v.49, p.149-161, 1994.

KROMP, B. Carabid beetles in sustainable agriculture: a review on pest control efficacy, cultivation impacts and enhancement. Agriculture, Ecosystems \& Environment, v.74, p.187-228, 1999.

LUFF, M.L. Carabid assemblage organization and species composition. In: HOLLAND, J.M. (Ed.). The agroecology of carabid beetles. Andover: Intercept, 2002. p.41-79.

MAGURA, T. Carabids and forest edge: spatial pattern and edge effect. Forest Ecology and Management, v.157, p.23-37, 2002.

MORAES, R.C.B. de; HADDAD, M. de L. Software para análise faunística-ANAFAU. In: SIMPÓSIO DE CONTROLE BIOLÓGICO, 8., 2003, São Pedro. Livro de resumos. Piracicaba: Sociedade Entomológica do Brasil, 2003. v.1, p.195.

NIEMELÄ, J. Carabid beetles (Coleoptera: Carabidae) and habitat fragmentation: a review. European Journal of Entomology, v.98, p.127-132, 2001. 
PFIFFNER, L.; LUKA, H. Overwintering of arthropods in soils of arable fields and adjacent semi-natural habitats. Agriculture, Ecosystems \& Environment, v.78, p.215-222, 2000.

RIESKE, L.K.; BUSS, L.J. Influence of site on diversity and abundance of ground- and litter-dwelling Coleoptera in Appalachian Oak-Hickory forests. Environmental Entomology, v.30, p.484-494, 2001.

SUENAGA, H.; HAMAMURA, T. Occurrence of carabid beetles (Coleoptera: Carabidae) in cabbage fields and their possible impact on lepidopteran pests. Applied Entomology and Zoology, v.36, p.151-160, 2001.
THIELE, H.U. Carabid beetles in their environments. Berlin: Springer, 1977. 369p.

THOMAS, C.F.G.; HOLLAND, J.M.; BROWN, N.J. The spatial distribution of carabid beetles in agricultural landscapes. In: HOLLAND, J.M. (Ed.). The agroecology of carabid beetles. Andover: Intercept, 2002. p.305-344.

WATT, A.D.; STORK, N.E.; BOLTON, B. The diversity and abundance of ants in relation to forest disturbance and plantation establishment in southern Cameroon. Journal of Applied Ecology, v.39, p.18-30, 2002.

Received on January 8, 2008 and accepted on January 26, 2009 